\title{
UPAYA PENANGGULANGAN TINDAK PIDANA PENYELUNDUPAN PEMALSUAN DOKUMEN KEPABEANAN DI INDONESIA
}

\author{
Oleh : \\ (Putu Sekarwangi Saraswati, SH.,MH) \\ Program Studi, Fakultas Hukum Universitas Mahasaraswati Denpasar \\ Jl. Kamboja, No. 11A, Dangin Puri Kangin, denpasar Utara, Bali 80233 \\ (sekarwangisaraswati@gmail.com)
}

\begin{abstract}
Abstrak,
Terjadinya tindak pidana penyelundupan dikepabeanan ini bukan saja dapat merugikan di sektor penerimaan pemasukan pajak dan bea masuk/cukai bagi negara, akan tetapi akan dapat mempengaruhi dan membawa sesuatu kebiasaan yang buruk dan negatif bagi suatu masyarakat. Dimana tindak pidana ini dapat dilakukan oleh suatu perusahan yang akan mengekspor barang-barang ke luar negeri atau mengimpor barang-barang dari luar negeri,, misalnya dengan memberikan dokumen kepabeanan yang palsu atau tidak sesuai dengan barang-barang yang di ekspor atau di impor. Tindak pidana penyelundupan pemalsuan dokumen kepabeanan selain faktor ekonomi, juga disebabkan oleh faktor geografis Indonesia, kualitas hasil industri dalam negeri, adanya larangan masuknya suatu jenis barang tertentu, longgarnya pengawasan, adanya tekanan pihak lain, pelaku itu sendiri tidak mengetahui bahwa telah melakukan tindak pidana penyelunudupan pemalsuan dokumen kepabeanan. Sedangkan upaya penanggulangannya dapat dilakukan secara preventif dan refresif.
\end{abstract}

\section{Kata Kunci: Penyelundupan, Kepabeanan, Penanggulangan.}

\begin{abstract}
,
The occurrence of these customs smuggling crimes cannot be changed in the sector of income tax and import duty / excise for the state, but will be able to influence and bring negative impacts. Where criminal acts can be carried out by bodies that will integrate goods abroad or translate goods from abroad, for example by providing customs documents that are not in accordance with goods exported or imported. Acts of smuggling in falsification of customs documents in addition to economic factors, also by factors in Indonesia, quality of domestic industrial products, including barriers to entry of certain types of goods, loosening of supervision, others, the perpetrators themselves do not know that they have committed fraud customs documents. Whereas prevention efforts can be done preventively and refresively.
\end{abstract}




\section{Keywords: Smuggling, Customs, Countermeasures.}

\section{Latar Belakang Masalah}

Negara Republik Indonesia adalah sebuah negara yang kaya akan sumber daya alam dan sumber daya buatan. Terlebih labih ditunjang dengan keuntungan letak geografis diantara 2 (dua) benua dan 2 (dua) samudra besar, maka sumber daya itu merupakan modal dasar bagi pembangunan rakyat dan negara dalam menghadapi tantangan dimasa yang akan datang. Dari sumber daya itu negara Indonesia dapat mengembangkan dan meningkatakan hasil untuk dieksport ke beberapa negara, sehingga dapat memperbesar penerimaan devisa dan meningkatkan pendapatan nasional. Negara Indonesia saat ini adalah merupakan salah satu negara yang sedang giat-giatnya melaksanakan pembangunan dalam segala aspek kehidupan rakyat dan pembangunan negara yang bersifat fisik. Oleh karena itu dibutuhkan dan diperlukan devisa negara yang besar untuk mencukupi kebutuhan Anggaran Pendapatan dan Belanja Negara (APBN). Dengan terpenuhinya APBN, maka negara Indonesia akan dapat dengan cepat melaksanakan pembangunan nasional dengan tujuan meningkatkan dan tercapainya kesejahteraan dan kemakmuran rakyat.

Berbagai daya dan usaha ditempuh oleh pemerintah Indonesia guna memperoleh pendapatan, misalnya dengan mengenakan pajak tidak langsung, yaitu berupa pungutan bea masuk melalui pintupintu masuk ke Indonesia, seperti pelabuhan laut atau bandar udara (bandara). Sebagaimana kita ketahui bahwa dalam dunia perdagangan antar negara, melalui pelabuhan laut dan bandara merupakan tempat keluar masuknya suatu barang, baik dari dalam negeri maupun luar negeri, sehingga diperlukan pengenaan pajak/bea masuk terhadap barang-barang yang keluar masuk dari Indonesia. Pembangunan perdagangan diarahkan untuk meningkatkan efisiensi perdagangan dalam negeri dan luar negeri, sehingga memperlancar arus barang dan jasa, mendorong pembentukan harga yang layak dalam iklim persaingan yang sehat, menunjang usaha efisiensi produksi, 
mengembangkan ekspor, memperluas lapangan pekerjaan dan kesempatan berusaha, meningkatkan pemerataan pendapatan rakyat serta untuk memantapkan stabilitas perekonomian nasional.

Mengenai kebijakan impor, yang ditujukan kepada peningkatan barang modal, bahan baku dan penunjang untuk pembangunan diberbagai bidang. Hal ini untuk memberikan perlindungan yang wajar bagi industri dalam negeri sekaligus menunjang usaha peningkatan efisiensi produksi barang-barang dalam negeri. Sedangkan pada kebijakan ekspor adalah dengan meningkatkan dan memperluas produksi untuk diekspor, khususnya barang-barang non migas. Kegiatan ini dilakukan dengan jalan memperluas pasaran, meningkatkan daya saing terhadap barang-barang ekspor, mempeluas pengangkutan, meringankan pajak dan lain-lainnya.

Untuk menunjang perkembangan perekonomian nasional, agar dapat berkembang dengan pesat dan dapat berjalan sesuai dengan kebijakan pembangunan nasional sebagaimana telah digariskan oleh pemerintah, maka dikeluarkanlah suatu peraturan perundang-undangan dibidang kepabeanan yaitu Undang-Undang Nomor 10 Tahun 1995 (UU No.10/1995). Meskipun dalam UU No.10/1995 telah melakukan kriminalisasi terhadap perbuatan-perbuatan digolongkan sebagai perbuatan pidana dan telah memuat sanksi-sanksi pidana yang tegas, tetapi masih saja terjadinya perbuatan-perbuatan penyelundupan terhadap suatu barang dan dokumen kepabeanan agar terhindar dari pajak atau bea masuk dalam praktek perdagangan dan perekonomian di Indonesia. Praktek penyelundupan pemalsuan dokumen kepabeanan itu tentu saja mempunyai maksud dan tujuan-tujuan tertentu, disamping menghindari pajak dan bea masuk, juga untuk mencari keuntungan yang yang bersifat pribadi dan berlipat ganda atau memang barang yang diselundupkan itu adalah barang yang dilarang untuk di impor ${ }^{11}$. Dimana tindak pidana penyelundupan pemalsuan
${ }^{11}$ Andi Hamzah, 1985 : Delik

Penyelundupan, Akademika Pressindo, Jakarta, hal. 36 (1) 
dokumen kepabeanan itu adalah merupakan suatu perbuatan yang dilarang mengimpor, mengekspor, mengantar pulaukan barang yang tidak memenuhi peraturan perundang-undangan yang berlaku atau tidak memenuhi formalitas kepabeanan/douane formaleitet yang ditetapkan oleh undang-undang ${ }^{12}$

Dengan adanya kebijaksanaan Pemerintah dibidang impor - ekspor, khususnya pembebasan pengangkutan antar pulau untuk tidak menggunakan dokumen muatan serta tujuan kapal yang dipalsukan, maka para penyelundup mulai memanfaatkan untuk menyelundupkan barang-barangnya melalui dokumen yang dipalsukan, dari dan keluar Indonesia, baik melalui darat, laut dan udara. Sehingga dengan demikian, pihak aparat penegak hukum (khususnya Petugas Bea Cukai dan kepolisian), telah menduga atau mensinyalir adanya kapal-kapal yang membongkar muatannya di pelabuhanpelabuhan pantai yang selama ini tidak pernah digunakan untuk bongkar - muat cargo, kecuali untuk bahan kebutuhan pokok $^{13}$. Didalam UU No.10/1995 yang

${ }^{12}$ Soufnir Chibro, 1992 : Pengaruh Tindak Pidana Penyelundupan Terhadap Pembangunan, Sinar Grafika, Jakarta, hal. 5 diberlakukan oleh pemerintah memiliki maksud dan tujuan untuk memberikan kemudahan bagi pengusaha melakukan penilaian sendiri/self-assessment, yaitu dengan mengisi sendiri dokumen tentang barang-barang impor-ekspornya. Namun dalam praktek atau kenyataannya sering muncul perbedaan antara hasil pemeriksaan petugas bea cukai dengan laporan dari pengusaha tentang jenis dan jumlah barang. Oleh karena itu, dalam hal ini sangat diperlukan suatu kejujuran dan keterbukaan antara kedua belah pihak atas dasar saling mempercayai, meskipun dalam praktek dilapangan masih sering diketemukan penyimpanganpenyimpangan terhadap sesuatu barang yang akan diselundupkan, baik lewat darat, udara dan laut.

\section{Kebijakasanaan-kebijaksanaan}

yang diambil dan dilakukan oleh pemerintah, baik berupa kelonggarankelonggran ekspor untuk memperoleh devisa maupun kelonggaran impor bahan baku, serta larangan barang tertentu dalam rangka melindungi industri maupun kebijaksanaan terhadap pendistribusian

\footnotetext{
${ }^{13}$ Andi Hamzah, op.cit, hal. 17 (1)
} 
perdagangan, memerlukan kecermatan dalam pengendalian dan pengawasan untuk mencegah penyalahgunaan. Penyalahgunaan gunaan yang dimaksudkan dapat berupa terjadinya tindak pidana penyelundupan pemalsuan dokumen kepabeanan, tindak pidana pengangkutan barang-barang hasil penyelundupan dan lain-lainnya ${ }^{14}$.

Terjadinya tindak pidana penyelundupan dikepabeanan ini bukan saja dapat merugikan di sektor penerimaan pemasukan pajak dan bea masuk/cukai bagi negara, akan tetapi akan dapat mempengaruhi dan membawa sesuatu kebiasaan yang buruk dan negatif bagi suatu masyarakat. Dimana tindak pidana ini dapat dilakukan oleh suatu perusahan yang akan mengekspor barang-barang ke luar negeri atau mengimpor barang-barang dari luar negeri,, misalnya dengan memberikan dokumen kepabeanan yang palsu atau tidak sesuai dengan barangbarang yang di ekspor atau di impor. Penyerahan dokumen palsu itu dapat berupa keterangan jumlah barang yang tidak benar dari yang sesungguhnya atau dapat juga berupa keterangan kuantitas atau jenis barang yang tidak sesuai dengan barang yang sesungguhnya. Dokumen atau keterangan palsu kepabeanan itu dapat juga berupa pemberian keterangan palsu secara lisan yang diberikan oleh seseorang yang ingin memasuki wilayah Republik Indonesia, misalnya seorang penumpang yang membawa barang-barang bawaannya tidak diketahui oleh pihak bea Cukai yang terdapat di pelabuhanpelabuhan/terminal/bandara dan memang sengaja tidak melaporkan barang bawaannya, maka orang itu sudah dapat dianggap melakukan penyelundupan suatu barang.

Pemalsuan dokumen kepabeanan baik yang dilakukan secara tertulis maupun memberikan keterangan lisan yang palsu, saat ini masih sering terjadi, baik yang dilakukan secara perseorangan maupun dilakukan oleh suatu perusahan, dengan maksud dan tujuan untuk memperoleh keuntungan ekonomi yang berlipat ganda/keuntungan besar untuk diri sendiri maupun perusahan. Tindak pidana pemalsuan dokumen kepabeanan ini diatur

\footnotetext{
${ }^{14}$ Laden Marpaung, 1994 :

Pemberantasan dan Pencegahan Tindak Pidana

Ekonomi, Sinar Grafika, Jakarta, hal. 2 (1)
} 
dalam pasal 103 UU No.10/1995, yang ancaman pidananya adalah dengan pidana penjara lima tahun dan/atau denda paling banyak Rp. 250.000.000.00,- (Dua Ratus Lima Puluh Juta Rupiah). Meskipun para ekportir dan impotir telah menyadari dan mengetahui bahwa ancaman pidana pemalsuan dokumen kepabeanan ini demikian berat dan besar, namun kenyataannya dalam pelabuhan/terminal/bandara besar, kejahatan ini masih tetap ada orang atau perusahan yang berani melakukan. Meningkatnya tindak pidana penyelundupan adalah merupakan salah satu kendala yang merugikan perekonomian negara dan sebagai hal yang dapat menghambat pembangunan nasional. Terjadinya tindak pidana ini, diperkirakan dipengaruhi oleh beberapa faktor, seperti luasnya wilayah Republik Indonesia, terdiri dari beberapa kepuluan sehingga banyak terdapat pintu-pintu masuk ke wilayah Republik Indonesia, kondisi industri dalam negeri yang belum mampu bersaing dengan barang impor, rendahnya pertisipasi masyarakat dalam bekerjasama dengan aparat pemerintah/aparat penegak hokum dan fakot-faktor lain yang saling memiliki hubungan kausal.

Berbagai usaha atau upaya telah dilakukan dan ditempuh oleh pemerintah Indonesia dalam mengatasi serta menanggulangi tindak pidana penyelundupan, seperti telah membentuk badan Koordinasi Keamanan Laut (Bakorkamla), Team Wali Songo, Team Pemantau Penanggulangan dan Pemberantasan Penyelundupan (TP4), Badan Koordinasi Pelaksana Instruksi Presiden Nomor 6 tahun 1971 (Bakorlak Inpres No.6/1971), namun terkesan semuanya mengalami kegagalan, oleh karena tindak pidana ini masih saja sering terjadi bahkan meningkat, terutama di pelabuhan-pelabuhan besar atau bendarabendara Internasional ${ }^{15}$. Bertitik tolak dari pemaparan singkat tersebut diatas, maka akan timbul permasalahan yaitu ;

1. Apakah ada faktor lain selain faktor ekonomi yang menjadi penyebab terjadinya tindak
${ }^{15}$ Moch. Anwar, 1982 : Segi-Segi Hukum Masalah Penyelundupan, Alumni, Bandung, hal. 146 
pidana

penyelundupan

pemalsuan

dokumen

kepabeanan dan bagaimana

upaya penanggulangannya ?

\section{BAB II PEMBAHASAN}

Tindak pidana penyelundupan dalam istilah/bahasa asingnya adalah “ smokkel ", adalah suatu perbuatan yang dilarang untuk mengimpor, mengekpor, mengantar pulaukan barang dengan tidak memenuhi peraturan perundang-undangan yang berlaku atau tidak memenuhi formalitas pabean/douane formaliteiten yang ditetapkan oleh peraturan perundangundangan $^{16}$. Disamping itu ada istilah tindak pidana penyelundupan administrasi yang dapat berupa perbuatan pemalsuan dokumen kepabeanan, yang dalam Pasal 103 (a) UU. No. 10/1995 menentukan bahwa, yang dimaksud dengan tindak pidana penyelundupan admintrasi adalah : "menyerahkan pemberitahuan pabean dan/atau dokumen pelengkap pabean dan/atau memberikan keterangan lisan atau tertulis yang palsu atau yang dipalsukan yang digunakan untuk

\footnotetext{
${ }^{16}$ Baharuddin Lopa, 1980 : Tindak Pidana Ekonomi, Pradnya paramita, Jakarta, hal. $32-33$
}

pemenuhan kewajiban pabean”. Yang dimaksud dengan dokumen pelengkap pabean adalah : semua dokumen yang digunakan sebagai pelengkap pemberitahuan pabean, invoice(faktur), bill of lading(sejenis uang kertas untuk pembayaran), packing list (daftar barang) dan manifest (daftar tentang muatan). Dalam penyelundupan administrasi perlu juga diperhatikan tentang daerah kepabeanan, bila barang tersebut masih didaerah pabean, dikatakan sebagai penyelundupan administrasi, oleh karena tidak sesuai antara barang yang sebenarnya dengan isi dokumen tentang jumlah, jenis dan harga yang dilaporkan, sedangkan jika telah keluar dari daerah kepabeanan, maka dikatagorikan sebagai penyelundupan fisik sebagai mana diatur dalam Pasal 26 b ordonantie bea Staatsblad 1882 Nomor $240^{17}$.

Dengan demikian tindak pidana pemalsuan dokumen kepabeanan ini merupakan memasukan dan mengeluarkan barang-barang yang lengkap dokumennya melalui pelabuhan, terminal atau bandara yang resmi (dari darat, laut dan udara).

\footnotetext{
${ }^{17}$ Laden Marpaung, 1991 : Tindak Pidana Penyelundupan, PT Gramedia, Jakarta, hal. $6(2)$
} 
Akan tetapi data-data yang tertulis dalam dokumen atau yang dilaporkandiberitahukan itu secara lisan kepada petugas tidak sesuai dengan yang sesungguhnya. Tindak pidana pemalsuan dokumen kepabeanan yang dilakukan oleh penumpang didasarkan pada Pasal 8 ayat (3) UU No. 10/1995, yang menentukan bahwa : " barang impor yang dibawa oleh penumpang, awak sarana angkutan atau pelintas batas dan daerah pabean pada saat kedatangan wajib diberitahukan oleh pembawanya kepada pejabat bead an cukai “. Sehingga para penumpang yang tidak melaporkan keadaan barang yang dibawa sesuai dengan dokumen yang dilaporkan, maka terhadapnya dapat dikenakan ketentuan Pasal 103 UU No. 10/1995, yaitu dapat diancam dengan sanksi pidana penjara paling lama lima (5) tahun dan /atau denda paling banyak Rp. 250.000.000,00,- (Dua Ratus Lima Puluh Juta Rupiah ).

Pengertian yang luas mengenai tindak pidana yang terjadi di kepabeanan bila dilihat dari penjelasan Pasal 103 tersebut diatas adalah dalam hal seseorang mengimpor atau mengekspor barang tanpa mengindahkan ketentuan atau prosedur yang telah ditetapkan oleh undang-undang ini, diancam dengan pidana berdasarkan pasal ini dengan hukuman akumulatif berupa pidana penjara dan atau pidana denda. Berdasarkan undang-undang ini, kepabeanan adalah segala sesuatu yang berhubungan dengan pengawasan atas lalu lintas barang yang masuk atau keluar daerah pabean dan pemungutan bea masuk. Dengan demikian, tindak pidana merupakan perbuatan yang dilakukan, baik karena kesengajaan maupun tidak, yang berupa penyelewengan atau menyimpangan dalam penyelenggaraan impor-ekspor barang. Pengertian yang sempit tentang penyelundupan ini terlihat dalam keputusan Presiden Nomer 73 Tahun 1967, Pasal 1 ayat (2), yang menyebutkan bahwa tindak pidana penyelundupan adalah tindak pidana yang berhubungan dengan pengeluaran barang atau uang dari Indonesia ke luar negeri (ekspor) atau memasukan barang atau uang dari luar negeri ke Indonesia (impor). Definisi ini menyimpulkan bahwa tindak pidana apa saja yang berhungan dengan pemasukan atau pengeluaran barang adalah tindak pidana penyelundupan dan membatasi hanya pada perbuatan 
pemasukan dan pengeluaran barang dan tidak termasuk antar pulau ${ }^{18}$

Pada umumnya bentuk penyelundupan dapat digolongkan menjadi 2 (dua) macam, yaitu :

1). Penyelundupan fisik, adalah pemasukan atau pengeluaran barang-barang baik dari luar negeri maupun ke luar negeri, tanpa dilindungi oleh dokumen-dokumen. Perbuatan ini bertujuan menghindarkan diri dari segala kewajibankewajiban ataupun larangan yang telah ditetapkan dalam ordonansi bea serta reglemenreglemen lampirannya dan peraturan-peraturan sebagai peraturan pelaksanaan dari ordonansi bea serta reglemenreglemen lampirannya.

2). Penyelundupan administrasi, adalah

pemasukan/pengeluaran barang-barang yang lengkap dokumen-dokumennya dan melalui pula instansi-instansi dan pelabuhan-pelabuhan resmi, tetapi data-data yang tertulis dalam dokumendokumen atau yang dilaporkan/diberitahukan kepada petugas bea cukai tidak sesuai dengan kenyataan barang yang sebenarnya dimasukan/dikeluarkan, kemungkinan dapat terjadi perbedaan jumlah, jenis atau kualitas harga atau dapat terjadi kedua-duanya atau ketiga-tiganya $^{19}$.

Penyelundupan administrasi berupa tindak pidana pemalsuan dokumen kepabeanan dapat juga dilakukan oleh seorang penumpang, yaitu pada waktu mengisi dan melaporkan dokumen angkutan. Dokumen angkutan bukan merupakan dokumen perjanjian angkutan, tetapi hanya merupakan salah satu bukti adanya perjanjian angkutan, karena tanpa dikeluarkan dokumen angkutan oleh pihak pengangkutpun adalah tetap ada perjanjian $\operatorname{angkutan}^{20}$. Oleh karena didalam praktek,

\author{
${ }^{20}$ E. Suherman, 1979 : Masalah \\ Tanggung Jawab Pada Charter Pesawat Udara
}

${ }^{18}$ Baharudin Lopa, op.cit, hal. 33

${ }^{19}$ Baharudin Lopa, ibid, hal. 65 
tiket penumpang dan tiket bagasi dibuat dalam satu dokumen angkutan, dimana barang bagasi asalah semua barang kepunyaan atau dibawah kekuasaan seorang penumpang yang atas namanya sebelum ia menumpang pesawat terbang diminta untuk diangkut melalui udara ${ }^{21}$.

Membicarakan masalah penyelundupan barang-barang yang akan dimasukan ke Indonesia baik dengan dokomen kepabeanan yang formal dan nyata maupun tidak, akhir-akhir sering terjadi di berbagai wilayah pelabuhan, terminal, bandara yang ada di Indonesia. Terjadinya penyelundupan itu sudah tentu akan mempengaruhi pendapatan negara melalui pajak dan bea masuk suatu barang secara illegal, sehingga pemasukan keuangan ke kas negara sangat sedikit dan dapat mempengaruhi perekonomian nasional. Menurut A. Abdurachman, delik-delik yang pada umumnya terjadi didaerah kepabeanan di Indonesia adalah antara lain ; tidak membikin penyelesaian pemberitahuan umum atau dokumendokumen yang menggantikan dokumen sebelumnya (Pasal 25 ke 1 sub b dan Pasal

dan Beberapa Masalah Lain Dalam Bidang Penerbangan, Alumni, Bandung, hal 32
26 ke 2 Ordonansi Bea Staatsblad 1882 Nomor 240), membongkar barang-barang yang tidak tercantum didalam pemberitahuan umum atau surat-surat yang menggantikan pemberitahuan itu (Pasal 25 ke 1 sub c dan Pasal 26 ke 2 Ordonansi Bea Staatsblad 1882 Nomor 240), membuat pemberitahuan yang salah mengenai jenis-jenis barang (Pasal 25 ke 2 sub c dan Pasal 26 ke 5 Ordonansi Bea Staatsblad 1882 Nomor 240), menyembunyikan barang-barang yang tercantum dalam suatu pemberitahuan, yang dibungkus dengan barang-barang lain (Pasal 25 ke 2 sub c dan Pasal 26 ke 5 sub b Ordonansi bea Staatsblad 1882 Nomor 240), memasukan barang-barang tanpa menghiraukan peraturan-peraturan kepabeanan (Pasal 26 b Ordonansi bea Staatsblad 1882 Nomor 240), mengangkut atau mengeluarkan barang-barang dengak tidak menghiraukan peraturan kepabeanan (Pasal 25 ke 1 sub c dank e 2 sub e dan Pasal 26 ke 3 dan ke 7 Ordonansi Bea Staatsblad 1882 Nomor 240), membuat pemberitahuan yang salah mengenai banyaknya/jumlah barang-barang (Pasal

\footnotetext{
${ }^{21}$ Sution Usman Adji, Djoko Prakoso dan Hari Pramono, 1990 : Hukum pengangkutan di Indonesia, Rineka Cipta, Jakarta, hal. 59
} 
25 ke 2 sub c dan Pasal 16 ke 5 sub c Ordonansi Bea Staatsblad 1882 Nomor 240), membuat pemberitahuan yang salah mengenai kadar barang cair yang diolah dengan alkohol sulingan dan barang cair itu adalah bukan minuman yang segera dapat dipakai, untuk menghitung bea masuknya, maka dilakukan penghitungan kembali sampai suatu kadar sebesar 50 persen dalam perbandingan sampai suatu kadar yang telah ditetapkan (Pasal 25 ke 2 sub e dan Pasal 26 ke 7 Ordonansi Bea Staatsblad Nomor 240) $)^{22}$. Dengan demikian, semua tindakan-tindakan atau perbuatan-perbuatan itu sudah dapat dikatakan sebagai suatu kejahatan atau pelanggaran, baik karena disengaja maupun tidak yang dapat merugikan pemasukan devisa atau penerimaan Negara dalam bentuk pajak pemasukan dan pengeluaran barang dari dan ke wilayah Indonesia. Sebagaimana dikatakan diatas, bahwa terjadi tindak pidana penyelundupan dokumen kepabeanan lebih banyak disebabkan oleh faktor yang bersifat ekonomis (menghindari pajak dan bea masuk) terhadap suatu barang, tetapi juga dapat disebabkan oleh :

1). Faktor georafis, yaitu bahwa Negara Indonesia sangat luas sekali yang terdiri dari beriburibu pulau dan diapit oleh 2 (dua) benua yang besar, yaitu Asia dan Australia serta 2 (dua) samudra yang samudra Hindia dan samudra pasifik. Diantara pulau-pulau dalam satu kesatuan Negara Republik Indonesia, juga dipisahkan oleh lautan yang cukup luas, sehingga demikian banyak terdapat pintu masuk ke wilayah Indonesia melalui pelabuhan laut. Dari kondisi wilayah Indonesia ini secara faktual, bahwa terjadinya tindak pidana penyelundupan terhadap suatu barang, yang akan dimasukkan ke Indonesia lebih banyak dilakukan melalui pelabuhan-pelabuhan laut, baik bersifat perorangan maupun berkelompok atas nama suatu

${ }^{22}$ Andi Hamzah, 1977 : Hukum Pidana

Ekonomi, Erlangga, Jakarta, hal. 98 (2) 
badan usaha, terutama sering terjadinya pemalsuan isi dokumen suatu barang.

2). Kualitas industri dakam negeri, yaitu kondisi hasil industri dalam negeri turut pula berperan terjadinya tindak pidana penyelundupan dokumen suatu barang, yang akan dimasukan ke Indonesia. Hal ini sebenarnya dapat disadari, bahwa hasil produksi industri suatu barang di Indonesia masih dalam tahap perkembangan dan pembinaan. Sudah tentu akan menghasilkan kuantitas dan kualitas barang tidak seperti hasil industri luar negeri, sehingga belum atau tidak mampu untuk bersaing dengan hasil industri negara-negara lain, seperti Amerika, Jepang dan Eropa pada umumnya.

3). Adanya larangan masuknya suatu jenis barang, yaitu bahwa tidak semua jenis barang dari luar negeri yang diperbolehkan masuk dan beredar di pasaran Indonesia. Dengan demikian sudah tentu aparat kepabeanan/bea cukai dan aparat penegak hukum lainnya, akan melarang suatu jenis barang itu masuk ke wilayah Indonesia. Adapun barangbarang itu misalnya memasukan atau mengangkut bahan-bahan narkotika tanpa dokumen yang syah/resmi atau memasukan bahan peledak atau memasukan minuman keras dengan kadar alkohol tinggi, sehingga bagi pelakunya akan ditindak sesuai dengan aturan-aturan hukum yang berlaku. Kemudian barang-barang itu akan disita dan para pelakunya akan dilanjutkan dengan prosesproses pemeriksaan hukum berikutnya ${ }^{23}$.

4). Longgarnya pengawasan, yaitu tidak cermat dan telitinya para putgas bea cukai dan aparat penegak hukum lainnya, dalam

${ }^{23}$ Baharudin Lopa, op.cit, hal. 41 
melakukan pengawasan dan pemeriksaan terhadap suatu barang akan dimasukan ke wilayah Indonesia. Bahkan disinyalir para aparat itu ikut bermain untuk meloloskan suatu barang yang dibawa dari luar negeri, untuk bisa lolos dari kepabeanan dan beredar di wilayah Indonesia. Dengan demikian mental dan moral aparat bea cukai dan aparat penegak hokum, juga sangat berperan untuk terjadinya tindak pidana penyelundupan dokumen terhadap suatu barang yang akan dimasukan ke Indonesia.

5). Tekanan pihak lain, yaitu seseorang sebenarnya menyadari bahwa perbuatan pemalsuan dan menyelundupkan dokumen yang dilakukan itu bertentangan dengan undangundang yang berlaku dan hati nuraninya sendiri. Namun karena adanya tekanan atau ancaman pihak lain, maka perbuatan itu dengan terpaksa dilakukan, mungkin orang yang menekan itu pernah berjasa terhadap si pelaku atau takut akan ancaman.

6). Pelaku tidak tahu bahwa telah melakukan tindak pidana.

Adakalanya seseorang pelaku yang ditangkap diwilayah kepabeanan karena membawa barang-barang yang melanggar peraturan dan dilarang untuk dimasukan ke suatu wilayah di Indonesia, tidak mengetahui barang itu adalah dilarang dan tidak mengetahui presedur untuk membawa atau memasukan/mengeluarkan barang itu ke dan dari wilayah Indonesia.

Didalam upaya penanggulangan terhadap tindak pidana penyelundupan dokumen kepabeanan, peranan Direktorat Jendral Bea Cukai tidak hanya hanya memungut dan mengenakan bea masuk dan pemeriksaan barang-barang impor dan ekspor, tetapi juga harus ikut dan berperan paling utama dalam menanggulangi terjadinya tindak pidana penyelundupan 
dokumen kepabeanan. Disamping itu, juga dapat melakukan koordinasi dan kerja sama dengan aparat penegak hukum lainnya, seperti kepolisian baik darat, air dan udara atau aparat penegak hukum lainnya, yaitu dengan cara :

a). Upaya preventif.

$$
\text { Upaya ini adalah }
$$
merupakan suatu cara yang ditempuh sebelum terjadinya tindak pidana dan untuk menghindari terjadinya tindak pidana penyelundupan pemalsuan dokumen kepabeanan. Upaya ini dapat dilakukan dengan mengadakan sosialisasi peraturan perundang-undangan yang berlaku dan berhubungan dengan keluar masuknya barang-barang dari dan ke wilayah Indonesia, mencantumkan sanksi pidana yang lebih berat terhadap para pelaku tindak pidana, membina dan mendidikan sumber daya manusia dalam lingkungan kerja Direktorat Dirjen Bea Cukai, menambah dan memperbaharui peralatan deteksi di kepabeanan, memperketat sistem keamanan dan keselamatan pengiriman barang-barang ekspor dan impor, pemerintah hendaknya berusaha untuk menanamkan dan menumbuhkan kesadaran masyarakat untuk lebih mencintai produk barangbarang industri dalam negeri. Upaya ini adalah tidak dilakukan dengan hukum pidana, akan tetapi merupakan upaya-upaya yang dilakukan tanpa menggunakan hukum pidana $^{24}$.

b). Upaya refresif.

Upaya penanggulangan yang bersifat refresif ini lebih menekankan pada proses penyelesaiannya melalui proses penangkapan, penahanan, penyidikan sampai dengan proses persidangan di

\footnotetext{
24 Djoko Prakoso, Bambang Riadi Lany dan Amir Muchsin, 1986 : Kejahatan-Kejahatan
} 


\begin{abstract}
Pengadilan, sesuai dengan peraturan perundang-undangan yang berlaku, baik terhadap hukum pidana formalnya maupun terhadap hukum pidana materiilnya. Disamping itu bilamana terbuktinya suatu perbuatan, maka aparat penegak hukum harus berani melakukan atau menjatuhkan sanksi pidana yang sesuai dengan ketentuan-ketentuan atau hukum yang berlaku. Juga dapat merampas barang-barang yang diselundupkan itu dengan menggunakan dokumen yang dipalsukan.
\end{abstract}

\section{BAB III PENUTUP}

Simpulan

Tindak pidana penyelundupan pemalsuan dokumen kepabeanan selain faktor ekonomi, juga disebabkan oleh faktor geografis Indonesia, kualitas hasil industri dalam negeri, adanya larangan masuknya suatu jenis barang tertentu, longgarnya pengawasan, adanya tekanan pihak lain, pelaku itu sendiri tidak mengetahui bahwa telah melakukan tindak pidana penyelunudupan pemalsuan dokumen kepabeanan. Sedangkan upaya penanggulangannya dapat dilakukan secara preventif dan refresif sebagaimana terlihat dalam pembahasan.

\section{DAFTAR PUSTAKA}

Andi Hamzah, 1985 : Delik Penyelundupan, Akademika Pressindo, Jakarta (1)

- 1977 : Hukum Pidana

Ekonomi, Erlangga, Jakarta (2)

Baharudin Lopa, 1980 : Tindak Pidana

Ekonomi, Pradnya Paramita, Jakarta

Djoko Prakoso, Bambang Riadi Lany dan

Amir Muchsin, 1986 : Kejahatan-Kejahatan

Yang Merugikan dan

Membahayakan

Negara, Bina Aksara, Jakarta

E. Suherman, 1979 : Masalah Tanggung

Jawab Pada Charter

Pesawat Udara dan

Beberapa Masalah

Lain Dalam Bidang 
Penerbangan, Alumni, Bandung

Soufnir Chibro, 1992 : Pengaruh Tindak

Pidana Penyelundupan 1991 : Tindak Pidana

Penyelundupan, PT Terhadap

Pembangunan, Sinar

Grafika, Jakarta

Gramedia, Jakarta (2)

Moch. Anwar, 1982 : Segi-Segi Hukum

Masalah

Penyelundupan,

Sution Usman Adji, Djoko Prakoso dan Alumni, Bandung Hari Pramono, 1990 : Hukum Pengangkutan Undang-Undang Nomor 10 Tahun 1995 di Indonesia, Rineka Cipta, Jakarta tentang kepabeanan

Laden Marpaung, 1994 : Pemberantasan

$\begin{array}{lr}\text { dan } & \text { Pencegahan } \\ \text { Tindak } & \text { Pidana } \\ \text { Ekonomi, } & \text { Sinar } \\ \text { Grafika, Jakarta (1) }\end{array}$

